\title{
Factors Influencing the Feed Intake and Live- weight Change of Beef Cattle on a Mixed Tree Savanna in the Transvaal
}

\author{
IBO ZIMMERMANN
}

\begin{abstract}
This study was conducted as part of a broad ecosystem project to identify and quantify some of the significant relationships between cattle and their environment. Over a period of 1 year, monthly measurements were made of Africander cattle ranging on mixed tree savanna in the Transvaal, Republic of South Africa. The following data were obtained: feed intake, liveweight change, crude protein content (CP) and digestibility of the diet, as well as the time which was spent feeding and mean bite size. Both $\mathrm{CP}$ and digestibility of diets influenced the liveweight change of the cattle, but only digestibility influenced their feed intake. Their daily feeding time was short enough and their mean bite size was large enough to suggest that the accessibility and distribution of preferred plant species within the savanna did not directly limit their feed intake. Nutritional requirements of the cattle could be estimated from relationships between some of the factors, the most accurate relationship being that between digestible $\mathrm{CP}$ intake and liveweight change of the cattle.
\end{abstract}

The quality of a diet can influence the feed intake of ruminants through its effects on the digestion in the rumen, and it can influence the growth of ruminants through its effects on the efficiency of converting the food to animal tissue (Blaxter 1962). In addition, the accessiblilty and distribution of food items amongst the vegetation can influence the feed intake and liveweight change of cattle, by limiting the amount of feed which the animals can harvest with each bite and so affecting the time which the animal spends feeding (Chacon et al. 1978). The objectives of the study discussed in this paper were to examine the influence of such factors on the seasonal feed intake and performance of free-ranging beef cattle. This information could be used together with results from other ecological studies conducted by the South African Savanna Ecosystem Project: "to develop the understanding necessary to predict changes in the ecosystems stability induced by various natural and man-made stresses" (Anon 1978). Furthermore, the quantification of relationships between nutritional factors and the liveweight change of cattle can provide estimates of the nutritional requirements of the cattle (Pearson 1972).

\section{Methods}

This study was carried out on the Nylsvley Nature Reserve situated in a mixed tree savanna of the Transvaal at $24^{\circ} 29^{\prime} \mathrm{S}$,

\footnotetext{
Author is research assistant, Mammal Research Institute, University of Pretoria, Pretoria 0002, South Africa.

This study formed part of a larger project supervised by Professor J.D. Skinner and Dr. G.K. Theron. I am grateful to the Transvaal Division of Nature Conservation for the use of facilities at Nylsvley Nature Reserve and to Mr. B.J. Huntley co-ordinator of the Savanna Ecosytem Project. This paper is a publication of the South African Savanna Ecosystem Project which was funded by the National Programme for Environmental Sciences, Council for Scientific and Industrial Research.

Manuscript received February 10, 1979.
}

$28^{\circ} 42^{\prime} \mathrm{E}$. Climatic data for the period of the cattle study are summarized in the Climatogram (Fig. 1), showing that most of the annual rainfall of about $630 \mathrm{~mm}$ fell during the hot, wet season from October/November to March. The soils of the reserve have been described by Harmse (1977) and the vegetation classified by Coetzee et al. (1976).

Twelve 2-year old Africander steers of about $325 \mathrm{~kg}$ liveweight were maintained in a single 190-hectare paddock for the duration of the study, May 1976 to April 1977. The paddock consisted mostly of Eragrostis pallens-Burkea Tree Savanna on poor sandy soils, interspersed with a few patches of Acacia-Eragrostis lehmanniana Short Tree Savanna on eutrophic soils. These were areas which had previously been occupied by subsistence farmers and were then preferred fecding sites of the cattle.

Samples of food eaten by the cattle were obtained each month from three esophageal fistulated steers, which were caught and sampled in the same places where they were found feeding, using the method of Alder (1969). Sampling was carried out for 30 minutes during the intensive feeding periods in the early morning

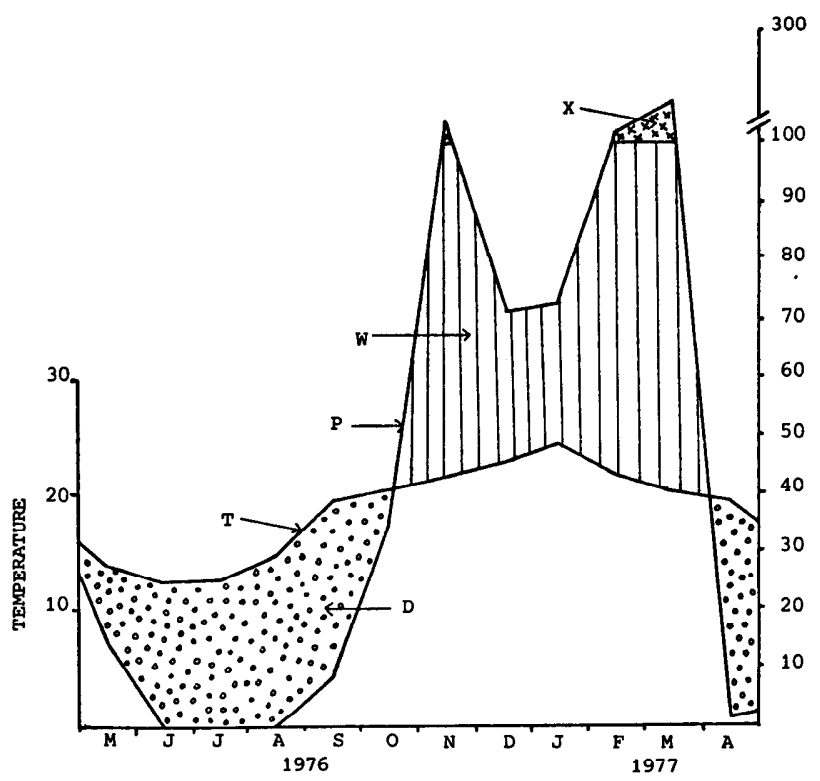


and late afternoon. A maximum of eight fistula samples were collected over a maximum of four consecutive days each month, collecting in turn from one steer at a time. In some months only six or seven samples could be obtained. These fistula samples were dried for 24 hours in a forced air oven at $70^{\circ} \mathrm{C}$ and hammermilled through a $0.5-\mathrm{mm}$ sieve for a nalysis of crude protein content (CP) in the dry matter (Kjeldahl nitrogen $\times 6.25$ ) and in vitro organic matter digestibility (IVOMD) by the method of Tilley and Terry (1963) modified slightly by the addition of $43.4 \mathrm{mg}$ urea per $\mathrm{ml}$ of artificial saliva. The IVOMD results were used as a measure of feed digestibility by converting to predicted in vivo digestibilities (henceforth referred to as digestibility) using the regression of Engels, et al. (1974).

Fecal output was measured directly by collecting the feces in bags attached by harnesses to a maximum of four nonfistulated steers each month for the same consecutive days that fistula samples were collected. In some months the results from only three or two steers were used because the harnesses of the other steers broke, but differences in the fecal output between different steers and different days of collection were not significant (Zimmermann 1978). The feces bags were weighed and emptied every 12 hours, and after thorough mixing a subsample of feces was taken to determine water content (by weighing before and after drying for 48 hours in a forced air oven at $70^{\circ} \mathrm{C}$ ) and for analysis of its $\mathrm{CP}$ content. The mean feces output for each month was used together with the monthly mean digestibility of the feed to calculate the feed intake for each month by:

$$
\text { Feed intake }=\frac{\text { Feces output } \times 100}{100-\text { Digestibility }}
$$

The cattle were allowed access to a nutrient lick in the form of a block which contained $27.5 \%$ protein and $8.5 \%$ urea as well as carbohydrates and various minerals. The average amount of lick consumed by the cattle was measured by weighing the amount given and the amount remaining each month. The lick consumption was taken into account when calculating the feed intake, its CP content and digestibility.

Each nonfistulated steer was weighed once a week and the mean liveweight at each week was plotted on a growth curve. There was some week-to-week variation in mean liveweight, probably due to differences in rumen fill, so straight lines were drawn to represent the probable mean liveweight change of each month.

One 24-hour behaviour study was carried out each month, in which the activity which the cattle were involved in at every fourth minute was recorded (Taylor et al. 1955). From this time spent by the cattle in feeding was calculated. Some direct feeding observations were also made by counting the number of bites which one particular steer took of different plant species during 15-minute periods. One observer (the author) carried out all the observations at a distance of about $4 \mathrm{~m}$ from the steer. The observations were usually carried out shortly after fistula sampling had taken place, so there were a maximum of eight observations per month from which a mean biting rate could be calculated.

Estimates of the amount of vegetation available to the cattle in the paddock each month were made by clipping in 30 evenly spaced quadrats $(0.5 \mathrm{~m} \times 0.5 \mathrm{~m})$ the plant material which was considered to be available to the cattle. This was then dried in a forced air oven at $70^{\circ} \mathrm{C}$ for 48 hours and weighed.

\section{Results and Discussion}

\section{Seasonal Changes in Nutritional Variables}

In Figure 2 the mean values for each month are plotted for digestibility CP content, feed intake, and liveweight change of the cattle (the latter two being expressed in terms of metabolic weight of $\mathrm{Wt}^{0.75}$ ). There was no apparent seasonal change in the amount of lick consumed by the cattle, and the average was only $0.91 \mathrm{gm} / \mathrm{Wt}^{0.75} /$ day. The average amount of CP obtained from the lick was $0.33 \mathrm{gm} \mathrm{CP} / \mathrm{Wt}^{0.75} / \mathrm{day}$, so
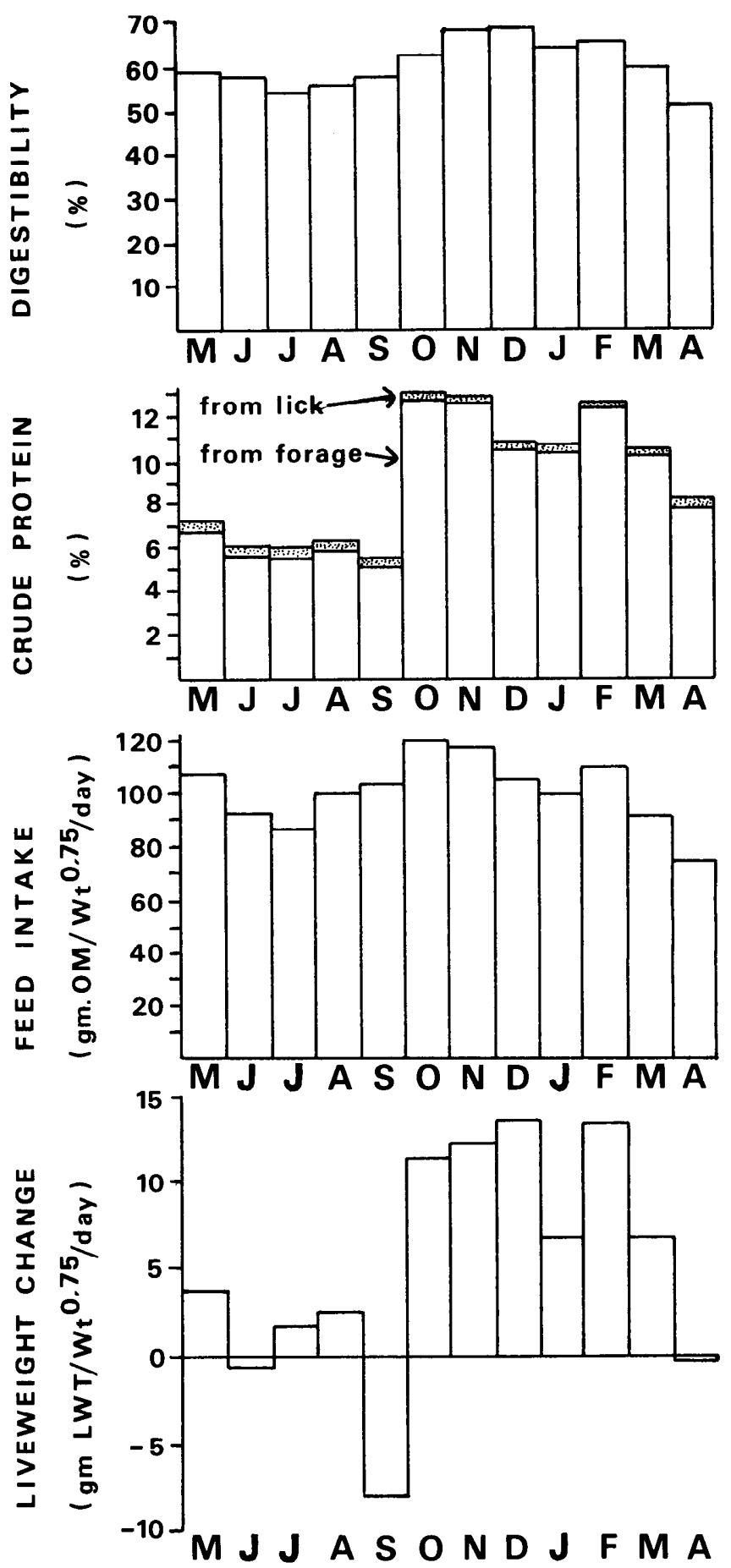

Fig. 2. Seasonal changes in the digestibility and crude protein content of the food, the amount of food eaten by the cattle, and their liveweight gains.

the cattle obtained about $2.4 \%$ of their total CP intake from the lick during the wet season and about $7.7 \%$ during the dry season. The CP content of the feed in Figure 2 is shown separately for CP from the forage and CP from the lick, but the difference which the lick consumption made to forage intake and digestibility is so slight that it is not shown in Figure 2.

All the factors in Figure 2 were significantly higher during the hot wet season. The CP content peaked at the beginning of the wet season in October, while the digestibility peaked in the middle of the wet season (November/December). The great increase in CP content in the diet from about $5.5 \%$ at 
the end of the dry season in September to over $13 \%$ at the beginning of the wet season was due partly to the greater amount of browsing in October. In all other months browse only formed an insignificant part (less than 1\%) of the cattle diets. In October the steers did a lot of browsing on the newly flushed leaves of the pceling bark of ochna (Ochna pulchra), which made up roughly $20 \%$ of the dry weight of their food consumption at this time; the fistula samples which contained some of these browse leaves had much higher CP contents than the other samples collected in October (Zimmermann 1978).

The monthly estimates of the cattle liveweight change in Figure 2 show that very little weight was gained in the dry season while a small amount of weight was lost in June and April. Furthermore in September at the end of the dry season when most of the vegetation was dry and of low quality, the cattle lost a considerable amount of weight. This, however, was due largely to the cattle eating some of the poisonous woody geophyte Dichapetalum cymosum, which has a large underground storage system and was flushing its new growth of leaf at this time.

\section{Relationship between Different Nutritional Variables}

Linear regressions were calculated to examine the relationships between the monthly estimates of various factors which are shown in Table 1 . The September result was omitted when the monthly estimates of liveweight change were related to other seasonal changes, because of the effect of Dichapetalum poisoning in this month.

Table 1. Linear regression equations relating mean monthly variables concerning nutritional ecology of cattle. All the regressions are significant to at least the $5 \%$ level.

\begin{tabular}{|c|c|c|c|}
\hline $\begin{array}{l}\text { Equation } \\
\text { Number }\end{array}$ & Linear regression equations & $\begin{array}{l}95 \% \\
\text { Confidence } \\
\text { limits }\end{array}$ & $\begin{array}{c}\text { Coefficient } \\
\text { of deter- } \\
\text { mination } \\
\left(r^{1} \text { or } R^{1}\right.\end{array}$ \\
\hline Eq. 1 & Intake $^{1}=1.69$ Digestibility $^{2}-1.9$ & \pm 17.2 & 0.56 \\
\hline Eq. 2 & $\begin{array}{l}\text { LWT change }^{3}=0.83 \text { Digestibility }- \\
4.41 .\end{array}$ & \pm 4.6 & 0.82 \\
\hline Eq. 3 & LWT change $=0.30$ Intake -24.1 & \pm 7.1 & 0.58 \\
\hline Eq. 4 & $\begin{array}{l}\text { LWT change }=0.36 \mathrm{DOM} \text { intake }{ }^{4}- \\
16.0\end{array}$ & & \\
\hline Eq. 5 & Intake $=2.53 \mathrm{CP}^{s}+77.7$ & \pm 21.3 & 0.32 \\
\hline Eq. 6 & LWT change $=1.70 \mathrm{CP}-9.7$ & \pm 5.0 & 0.79 \\
\hline Eq. 7 & Digestibility $=1.51 \mathrm{CP}+46.9$ & \pm 7.2 & 0.59 \\
\hline Eq. 8 & $\begin{array}{l}\text { LWT change }=0.50 \text { Digestibility }+ \\
0.91 \mathrm{CP}-32.32-\end{array}$ & & 0.91 \\
\hline Eq. 9 & LWT change $=1.27 \mathrm{CP}$ Intake $6-5.9$ & \pm 4.3 & 0.84 \\
\hline Eq. 10 & $\begin{array}{l}\text { LWT change }=1.72 \text { DCP Intake }{ }^{7}- \\
4.0\end{array}$ & \pm 3.6 & 0.89 \\
\hline Eq. 11 & $\begin{array}{c}\text { Intake }=1.59 \text { Digestibility }=0.50 \mathrm{CP} \\
1.15\end{array}$ & - & 0.60 \\
\hline
\end{tabular}

Intake $=$ Organic matter food intake per metabolic weight of steer (gm IM/WT T. $^{0.73}$ /day.)

2Digestibility $=$ Organic matter digestibility of the cattle diets $(\%)$

${ }^{3} \mathrm{LWT}$ change $=$ Liveweight change of the cattle $\left(\mathrm{gm} \mathrm{LWT} / \mathrm{Wt}^{\mathrm{0m}} / \mathrm{day}\right)$.

${ }^{4} \mathrm{DOM}$ Intake $=$ Digestible organic matter intake per metabolic weight of steer (gm $\mathrm{DOM} / \mathrm{Wt}^{0.73} /$ day).

${ }^{5} \mathrm{CP}=$ Crude protein content of cattle diets $(\%$ in dry matter).

${ }^{6} \mathrm{CP}$ Intake = Crude protein intake per metabolic weight of $\operatorname{steer}\left(\mathrm{gm} \mathrm{CP} / \mathrm{Wt}^{0.73} /\right.$ day $)$. ( DC P Intake $=$ Apparent digestible crude protein intake per metabolic weight of steer
(gm DCP $/ \mathrm{Wt}^{0.73} /$ day).

Equation (Eq) 1 in Table 1 shows that digestibility of the feed correlated to some extent with the feed intake of the cattle $\left(r^{2}=0.56\right)$. Since digestibility and feces output were both used to calculate feed intake, the variations in feces output contributed less to intake variability.
Good relationships are generally found between digestibility of feed and intake of ruminants (Holmes and Jones 1965), but Thomas and Campling (1976) concluded that at high levels of digestibility (over 70\%), there may no longer be any relationship. At lower levels of digestibility, it is primarily the rate of fermentation of the cellulose and hemicellulose content of the food which determines the rate of passage of food through the rumen and hence the feed intake (Blaxter 1962). Since digestibility is often related to the rate of fermentation in the rumen, there is also some relationship between digestibility and intake.

Digestibility correlated well with the liveweight change as seen from Eq. 2 in Table $1\left(r^{2}=0.82\right)$; but since Eq. 1 gave a poorer correlation, the influence of digestibility on liveweight change does not seem to have been due mostly to the influence of digestibility on feed intake. In fact the feed intake did not correlate particularly well with the liveweight change as seen in Eq. $3\left(r^{2}=0.58\right)$ while the digestible organic matter intake resulted in a better correlation to liveweight change (Eq. $4 r^{2}=0.78$ ). The fact that digestibility is an integral part of the digestible intake is probably the reason why digestibility correlated better with liveweight change than with feed intake.

From Eq. 2 and 4 it would seem that for maintenance these steers would require food with a digestibility of about $53 \%$ or a digestible organic matter (DOM) intake of about $44 \mathrm{gm} \mathrm{DOM} / \mathrm{Wt}^{0.75} /$ day. This is somewhat higher than the maintenance requirement of about $30 \mathrm{gm} \mathrm{DOM} / \mathrm{Wt}^{0.75} /$ day determined by Elliot et al. (1961) for Africander cows ranging on Brachystegia savanna in Rhodesia.

The CP content of the food correlated poorly with the feed intake (Eq. 5, $r^{2}=0.32$ ) but correlated more closely with the liveweight change of the cattle (Eq. $6, r^{2}=0.79$ ); however, since there is also some degree of relationship between $C P$ content and digestibility of the food (Eq. 7, $r^{2}=0.59$ ), it was not clear whether the relationship between $\mathrm{CP}$ and liveweight change was due to auto correlation. A multiple linear regression performed on the data, using both CP and digestibility as independent variables on liveweight change (Eq. 8 ), gave an $R^{2}$ of 0.91 . This is an improvement on using either digestibility alone (Eq. $2, r^{2}=0.82$ ) or $\mathrm{CP}$ alone (Eq. 6 , $r^{2}=0.79$ ), so both CP and digestibility of the food had some influence on the liveweight change of the cattle. Since these factors are both used in calculating the CP intake and the apparent digestible crude protein (DCP) intake of the cattle, it is not surprising that the liveweight change correlated well with the CP intake (Eq. 9, $r^{2}=0.84$ ) and with the DCP intake (Eq. 10, $r^{2}=0.89$ ) from which maintenance requirements can be estimated as $4.7 \mathrm{gm} \mathrm{CP} / \mathrm{Wt}^{0.75} /$ day or $2.3 \mathrm{gm} \mathrm{DCP} /$ $\mathrm{Wt}^{075} /$ day. The latter is somewhat lower than the maintenance requirement for nonlactating Africander cows of about $2.5 \mathrm{gm} \mathrm{DCP} / \mathrm{Wt}^{0.75} /$ day calculated from the data of Elliot et al. (1961). From Eq. 6 it was estimated that the steers needed food with a CP content of about $5.7 \%$ for maintenance. Plowes (1957) reported that Africander cattle grazing in Rhodesia required a CP content in the feed of 5-6\%; and Karue (1975) reported that to supply the minimum protein requirements for maintenance of East African zebu cattle, grass with a CP content of about $7 \%$ was required. Equations 2-6 together with Eq. 9 and 10 could be used to estimate the nutritional requirements of the steers for particular liveweight changes.

Multiple linear regression of $C P$ and digestibility on the feed intake of the cattle gave an $R^{2}=0.60$ (Eq. 11) which is 
almost the same as digestibility alone (Eq. $1 r^{2}=0.56$ ). Therefore it seems that CP content of the forage did not affect feed intake; the small amount of correlation existing between these two factors (Eq. 5, $r^{2}=0.32$ ) must have been due to the influence of digestibility.

Digestibility and CP content were obviously not the only factors which influenced the cattle liveweight changes since even the best correlation in Table 1 only gave a coefficient of determination of 0.91 (Eq. 8). Factors such as other nutrients, toxic compounds, prevalence of internal parasites, and the adaptability of rumen microbes to change in feed quality might also have had some influence. Such factors might have been partly responsible for the reduced liveweight gains by the cattle in January and March for example.

\section{The influence of Feeding Behaviour}

The results from the behaviour studies were insufficient to indicate seasonal changes in feeding time probably because the day-to-day variation was too great so that results from one day did not represent the average for the month. However, the results from all 12 months were used to calculate a mean daily feeding time of $546 \pm 52$ minutes $(95 \%$ confidence limits).

The longest feeding time recorded was 666 minutes during the October behaviour study; this was probably due to the considerable amount of browsing which occurred at this time. Since cattle are not well adapted for browsing (Hafez and Schein 1962), they presumably had to spend more time for each unit of intake than they would when grazing; so the higher CP content of the browse probably warranted the extra time spent consuming it, since there was already sufficient good quality grass by this time (Zimmermann 1978).

During the progessive defoliation of a grass sward, Chacon et al. (1978) found that cattle increased their feeding time up to a peak and then decreased their feeding time as even less suitable herbage became available. They found that this decreased feeding time greatly reduced the feed intake, and presumably it occurred because the extra maintenance requirements of longer feeding times were not worth the effort. The daily feeding time of zebu steers in Zambia was found by Smith (1959) to vary from 480 minutes during the wet season to about 780 minutes during the dry season when the steers were losing weight. This latter feeding time probably approaches the maximum which cattle could achieve, since no data were found in the literature to indicate longer feeding times. The condition of the vegetation at Nylsvley does not appear to have been too poor, since all the daily feeding times observed were considerably less than 780 minutes.

The biting rate data were unreliable for the months May to July, and even for the other months they were too variable to indicate seasonal changes. The results from these other 9 months were used to calculate a mean biting rate, which was then used together with feed intake results and daily feeding time results to calculate a mean bite size for each month. When averaged over the 9 months the mean bit size was 0.34 $\pm 0.07 \mathrm{gm} \mathrm{OM}$ per bite. From theoretical considerations Stobbs (1974) calculated that the critical level for a $400-\mathrm{kg}$ animal to achieve adequate intake is $0.3 \mathrm{gm} \mathrm{OM}$ per bite. Since the average liveweight of the steers at Nylsvley rose from $255 \mathrm{~kg}$ to $395 \mathrm{~kg}$ over the year of the study, it seems that the bit size which they were able to achieve was large enough to have resulted in adequate feed intake.
The estimates of the amount of plant material available to the cattle varied from about $500 \mathrm{~kg} / \mathrm{ha}$ in September to about $960 \mathrm{~kg} / \mathrm{ha}$ in March. So even in September the amount of forage consumed by the 12 steers was less than $0.1 \%$ of what was available. However the cattle were highly selective amongst the plant material for plant species, plant parts, and plant material of different growth stages, and there was some competition from wild herbivores for the preferred material (Zimmermann 1978). So although there was plenty of material available to the cattle, the distribution of the preferred material amongst the vegetation could still have had a significant influence on the cattle feeding.

\section{Conclusions}

Under the conditions of this study, both the digestibility and $\mathrm{CP}$ content of the food eaten by the cattle had roughly the same influence on their liveweight change. However, in neighbouring Botswana, Pratchett et al. (1977) concluded that CP content of the food had a greater influence on cattle liveweight gains than did digestibility, so the relative influence of $\mathrm{CP}$ and digestibility can vary, possibly depending on the combination in which they occur and their association with other factors such as minerals and toxic compounds.

The fact that CP content of the food per se had no influence on the feed intake of the cattle would suggest that the CP levels experienced in this study were not limiting to the rumen microbes. When the amount of $\mathrm{CP}$ per unit of digestible $\mathrm{OM}$ is very low, then the feed intake of ruminants can be limited (Weston 1967). Since CP content did not affect the liveweight change of the cattle but not their feed intake, it seems that a unit of DM intake with a high CP content will be converted more efficiently to animal tissue than intake with a lower CP content.

It seems probable that the cattle were managing to fill their rumens, since digestibility correlated reasonably with the feed intake, so it seems unlikely that the distribution and accessibility of food items amongst the vegetation were directly limiting the feed intake. This conclusion is supported by the relatively short daily feeding times and the relatively large mean bite size which the cattle were able to achieve. However it is likely that the accessibility and distribution of food items were indirectly limiting the feed intake by influencing the quality of the diet which the cattle could obtain in their bites, particularly since the most common grass, Eragrostis pallens, was largely avoided by the cattle (Zimmermann 1978).

\section{Literature Cited}

Alder, F.E. 1969. The use of cattle with oesophageal fistulae in grassland experiments. J. Br. Grassld. Soc. 24:6-13.

Anonymous. 1978. Nylsvley - A South African savanna ecosystem project: objectives, organization and research programme. S. Afr. Nat. Sci. Programmes Rep. 27:1-35.

Blaxter, K.L. 1962. The Energy Metabolism of Ruminants. Hutchinson, Scientific and Technical, London. 329 p.

Chacon, E.A., T.H. Stobbs, and M.B. Dale. 1978. Influence of sward characteristics on grazing behaviour and growth of Hereford steers grazing tropical grass pastures. Aust. J. Agr. Res. 29:89-102.

Coetzee, B.J., F. van der Meulen, S. Zwanziger, P. Gonsalves, and P.J. Weisser. 1976. A phytosociological classification of the Nylsvley Nature Reserve. Bothalia 12:137-160.

Elliot, R.C., K. Fokkema, and C.H. French. 1961. Herbage consumption studies on beef cattle, I. Intake studies on Africander and Mashona cows on veld grazing -1959/60. Rhod. Agr. J. 58:124-130.

Engels, E.A.N., M.A. Baard, and A. Malan. 1974. Estimation of forage intake of pasture using faecal nitrogen concentration and in vitro digesti- 
bility results. Agroanimalia 6:81-86.

Hafez, E.S.E., and M.W. Schein. 1962. The behaviour of cattle. In: The behaviour of domestic animals. Edited by E.S.E. Hafez. Bailliere, Tindal, and Cox, London. p. 247-296.

Harmse, H.J. von M. 1977. Grondsorte van die Nylsvley-natuurreservaat. S. Afr. Nat. Sci. Programmes Rep. 16:1-64.

Holmes, W., and J.G.W. Jones. 1965. The feed intake of milk cows. II. The effect of roughage quality during late pregnancy and lactation. Anim. Prod. 7:39-51.

Karue, C.N. 1975. The nutritive value of herbage in semi-arid lands of East Africa. II. Seasonal influence on the nutritive value of Themeda triandra. E. Afr. Agr. For. J. 40:372-387.

Pearson, H.A. 1972. Estimating cattle gains from consumption of digestible forage on Ponderosa Pine range. J. Range Manage. 25:18-20.

Plowes, D.C.H., 1957. Seasonal variation in crude protein in twenty common veld grasses at Matopos, Southern Rhodesia, and related observations. Rhod. Agr. J. 54:33-55.

Pratchett, D., B.G. Capper, D.E. Light, M.D. Miller, A.S. Rutherford, T.W. Rennie, N.G. Buck, and J.C. Trail. 1977. Factors limiting liveweight gain of beef cattle on rangeland in Botswana. J. Range
Manage. 30:442-445.

Smith, C.A. 1959. Studies on the Northern Rhodesia Hyparrhenia veld. Part 1. The grazing behaviour of indigenous cattle grazed at light and heavy stocking rates. J. Agr. Sci., Camb. 52:173-178.

Stobbs, T.H. 1974. Components of grazing behaviour of dairy cows on some tropical and temperate pastures. Proc. Aust. Soc. Anim. Prod. 10: 299-302.

Taylor, J.I., D.H.L. Rollinson, and K.W. Harker. 1955. Studies on the habits of zebu cattle. II. Individual and group variation within a herd. J. Agr. Sci. Camb. 45:257-263.

Thomas, S. and R.C. Campling. 1976. Relationship between digestibility and faecal nitrogen in sheep and cows offered herbage ad libitum. J. Br. Grassld. Soc. 31:69-72.

Tilley, J.M.A., and R.A. Terry. 1963. A two-stage technique for the in vitro digestion of forage crops. J. Br. Grassld. Soc. 18:104-111.

Weston, R.H. 1967. Factors limiting the intake of feed by sheep. II. Studies with wheaten hay. Aust. J. Agr. Res. 19:983-1002.

Zimmermann, I. 1978. The feeding ecology of Africander steers (Bos indicus) on mixed bushveld at Nylsvley Nature Reserve, Transvaal. M.Sc. Thesis, Univ. of Pretoria. 